\title{
KNOWLEDGE IN HEGEL'S EARLY WORKS
}

\author{
Fabio Dasilva \\ Notre Dame University
}

\begin{abstract}
Most contemporary work in the realm of the sociology of knowledge, it is here contended, has focused primarily on objectified forms and on the analysis of their relationships. In so doing they have evaded the real dynamics of knowledge and the links thereof between objectified knowledge and epistemology. Recent work, such as that by Berger and Luckmann, presents a more comprehensive approach. Nevertheless, an examination of Hegel's early theological writings reveals in more detail the complexity of the dynamic process of knowledge, $i$ ts objectification and transformation. This essay takes for consideration the analysis of some of these dimensions present in Hegel. It focuses in particular on: the 'break' and re-unification; the relationship between immediacy and mediation, and the general structure of the context of knowledge and knowing.
\end{abstract}

With regard to the usual conceptions in the sociology of knowledge this paper might appear unusual. The realm of the sociology of knowledge is generally identified in contemporary American sociology as having developed from Wissensoziologie. This cultural transposition has interesting implications even at the linguistic level. The English translation for instance reduces to a single word both the verbal and substantive forms of Wissensoziologie so that these dimensions become obscured. This ambiguity does not occur in other linguistic systems, for instance:

as a verb:ไrw̋ళrar, noscere, kennen, connaitre (to know)

as a substantive: $\varepsilon^{\prime} \mathcal{L} \partial \mathcal{V} \mathcal{} \alpha$, scire, wissen, savior (knowledge)

Thus, in a strict sense, Wissensoziologie refers to a sociology of substantivated knowledge, which evades the processual formulation where subject-object and the category of mediation between them becomes crucial.

The positing of such a question immediately reveals two different results, even in the most systematically developed approaches to a sociology of knowledge, those of Karl Mannheim and Max Scheler. On the one hand there is the dichotomization of the enterprise into two approaches, the "structurally" oriented sociology of knowledge and the "sociology of the mind." Secondly, there is the unitary approach that focuses upon theoretical concerns at the level of the mind. Thus, in Mannheim's orientation the unity of the processes of knowing and of knowledge are formally split into two realms. Regarding Max Scheler's orientation, he "identifies to know and the knowledge of the essential structure of everything that 
is" and adds two other realms, inductive knowledge of science and metaphysical knowledge, that, in a strict sense, escapes the realm of the sociology of knowledge (Max Scheler, 1926;1928).

The problem of identifying the crucial issue in the sociology of knowledge becomes first an attempt to isolate a formulation in which taxonomic objectifications or reductionistic perspectives are not required. We assume that this is the case with Hegel. Consequently, we choose to examine Hegel's early works as the initial step in identifying the most crucial categories in a sociology of

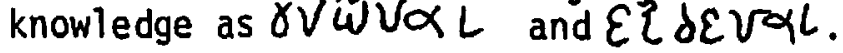

\section{The Early Development}

The analysis of the contributions of the young Hege 1 , beginning with Dilthey (Jugendgeschichte Hegels, 1921), has re-oriented the study of the process of development of Hegelian thought. When the concerns of a religious and ethico-political nature (that inspired the writings of the young Hegel) are identified, the genesis of Hegelian dialectics can no longer be unders tood exclusively through its confrontation with the Kantian dialectics and the doctrinal formulations of Fichte and Schelling. It must rather be followed through its gradual development as an instrument to solve the religious and ethico-political problems that emerged in a period preceding the "speculative" meeting of the young Hegel with the philosophy of Fichte and Schelling, and also with the "critique of pure reason" of Kant and the on-going debate about such a contribution.

It should be noted that at the moment that Hegel addressed the Kantian theoretical test and took a position regarding the doctrinal formulations of Fichte and Schelling (as well as that of Jacobi), the dialectic was already a defined structure. In other words, the Hegelian dialectic can no longer be interpreted as a product of the "dialectical method" as presented by Kant and modified by Fichte and Schelling but must be considered in relation to the central problems of the young Hegel's thought.

In fact, it is in his works from the Frankfurt period (from 1797 to 1800) that we first detect the organic determination of the Hegelian dialectic structure, although the word "dialectic" is absent (see in particular Häring, 1929-38). The writings of this period systematically merge the motives that had been delineated in the years at Tübingen and Berne; these are primarily Volksreligion und Christentum (1793-4), Das Leben Jesu (1795), and the first writing of Positivitat der christlichen Religion (1795-6). The following motives directed Hegel to the question of "break" and "reunification": the critique of Christianism in the name of an ideal Volksreligion that supports the organic integration of the individual in the social body; the identification of this ideal in ancient religion as a coherent expression of the structure of the Greco-Roman state and the "harmonic" existence of man in classical antiquity; the antithesis of the "happiness" in ancient religion as found in the "unhappiness" of Hebraic religion through an analysis of the meaning of the predication of Jesus; the dissemination of Jesus' teachings through the "positivism" of Christianism; and readings of German and French thought. It is in the formulation of the problem of "break" (Trennung) and "reunification" (Vereinigung) that the Hegelian dialectic consolidates. 
Al though an exhaustive analysis of the development of Hegelian thought is not appropriate here, some attention may be given to the way that Hegel reached the problem of "break" and "reunification."

The young Hegel's critique of religion is not directed to a return to a religion of the Enlightenment, nor to a confrontation with the Enlightenment and its program of intellectual civilization (Hegel, 1793-1794; Dilthey, 1907), nor to the appeal of Kant's ideal of religion "at the limit of pure reason," that is, religion only as ethics. The source of such a critique is volksreligion as an integral element of community, contributing to the formation of the "spirit of the people," as an organic totality in which the various manifestations of social life merge.

Volksreligion must represent the concrete historic mediation of the strategy of natural religion, based upon rational principles, and positive religion organized through statutory norms and supported by faith and tradition. On the basis of such a framework, considered as a critical device, the young Hegel enters the polemic directly in confrontation to Christianism. In contraposition to the Enlightenment, he sees Christian religion. not as a Volksreligion but rather as a "private religion." Moreover, he notes that such religion was continuously changing on the basis of interaction with the historical environment in which it emerged and had thus degenerated into a form of positive religion. Originally, the content of Jesus' predications was of a moral nature, an appeal to virtue. But then the figure of Jesus was interpreted as that of a "super-human ideal of virtue" (Noh1, 1907:57), as a personified ideal of "moral perfection" (Noh1, 1907:67). On such a basis, Christianity constructed its dogmatic edifice so as to reconcile ideologically God and the world given to Jesus. Thus, Christianity developed a positive religion, a religion based on authority.

From the original framework of the young Hegel's thought is derived a complex of problems, taken into consideration first during his residence at Berne and then at Frankfurt in Der Geist des Christentums und sein Schicksal (1798-9). Briefly, this complex includes: a) determination of the context of jesus" predications; b) explanations of the transformation of Christianism into a positive religion by referring to the historical conditions of the environment in which it emerged and the socio-political situation of the Roman empire; and c) determination of the differences between ancient classical religion and Christianism based on their various social functions.

The basis of Hegel's answer to these problems in Das Leben Jesu is clearly a Kantian interpretation of the evangelical message. Jesus predication is purely moral; it is an appeal to spiritual essences in opposition to the letter of the law, and thus not yet a teaching of statutory norms but rather teachings at virtue. How a religion of authority, organized according to dogma and incorporated into institutions, could emerge from such a religion of freedom is analyzed and explained in the first volume of his Positivität des christlichen Religion. His explanation is based upon an examination of the religious social context of the Hebrews. According to Hegel, the religion of the Hebrews is one that does not admit a dimension of freedom (the covenant and the law correspond to the servitude of man). Furthermore, God is radically distant from human life. These characteristics of the Hebrew religion, which Jesus opposed, nevertheless determined the nature of his own teachings, since they emerged from the Judaic context. They did so to such an extent that the moral teachings that were originaliy central as precepts (not as Laws) "lost the internal criteria of necessity" (Noh1, 1907:165), and these precepts were transformed into positive 
commands. Moreover, with the encounter of these developments with the myth of the Messiah that pervaded Hebrew culture, the figure of Jesus is transformed into that of a supra-human being, and "the doctrine of Jesus becomes the positive faith of a sect" (Noh1, 1907:166). The teachings of Jesus are thus institutionalized with a basis in the organization of the Church, which through history elaborates its dogmas and creates a structure of the state type, and yet in opposition to the State (Nohl, 1907:173-175, 183-205).

In contrast, the classic ancient religion as a Volksreligion was organically integrated with the life of the people, responding to the daily needs of social existence. Christianism was a positive religion that soon gave birth to an ecclesiastical organization in competition, and often in conflict, with the organization of the State and its requirements on the daily life of the people. The relationships of Christianism with the State, as opposed to ancient classical religion, reflects the metaphysical opposition of God's being and human life.

In Hegel's writings between the years at Tübingen and Berne, particularly in the essay Die Positivität der christlichen Religion, his interest in religion and in ethico-political questions was actualized in historical research. The critique of Christianism is further developed through the delineation of a historiographic framework that must support the structure of the history of Christianism and the structure of positive religion. The development of "positivity," a problem to be solved through historical analysis, is viewed as a problem of decadence, degeneration, for which the coalitions must be specified. In the Systemfragment (1800), Hegel's thought is even more complex; "positivity" appears as the result of a "break" interpreted metaphysically. This break must result from the historical process and is to be interpreted and then eliminated to re-establish simultaneously the unity of man and social reality and non-positivity of religion. There are some specific elements that can enlighten such transition of Hegel's thought, and they result from the change in German ideas since kant and from the influence of the Sturm und Drang in the framework of romantic culture. Sturm and Drang offers a critique of Kantian ethics and is added to the influences that Hegel receives from the interpretation of religious life offered by Schelling, the influence of Fichte's Wissenschaftslehre (that had published his Vom Ich als Prinzip der Philosophie in 1795), and the exchanges with Holderlin (Hoffmeister, 1931). Moreover, while these intellectual elements underline the transformations of Hegel's thinking, the changes in European politics, from the French revolution to the Napoleonic period, which supported a gradual withdrawing of republican ideals, led to the development of quite contrasting ideological formulations.

Thus, these processes have a bearing on the reinterpretations of early religious thought. The God of Abraham is totally extraneous to the life of his people and is "the infinite object, the complex of one truth and one relation, thus, the only properly subjective infinite" (Nohi, 1907: 250), in the face of whom man does not retain any margin of autonomy and becomes a simple "property of God" (Noh1, 1907:251), totally passive in such confrontation. Between God and human life there is then an irreparable "break," the roots of "unhappiness" of the Jewish people, which influences even the socio-political history of their society, so different from the classical world. The same break occurs in Christianism inasmuch as it withdraws from the original character of Jesus' predications and changes them into a positive religion. The themes of these analyses are similar to those that Hegel previously considered in Berne, but the emphasis 
is quite different. Now the teachings of Jesus are no longer considered as purely moral but are rather characterized according to the Kantian framework as establishing a "religion of virtue." Moreover, there is an added emphas is on the love relationship between God and man. With the change into positive religion, such a love relationship is replaced by the obedience of man to codified pirecepts. Thus, Hegel's interpretation of Jesus' predications changes, and, correspondingly, there is a shift to the valuation of ethics and of the relationships between ethics and religion. In any event, the changes in historical interpretation are subordinated to the critical position taken by Hegel to the Kantian interpretation of religion. In fact, the "break" in the religious realm that is expressed both in Judaism and Christianism also constitutes the basis of ethics regarding the dominance of the imperatives that interfere with the tendencies of man. The antagonism between law and human inclination is the structural element of the ethics: the "must be" is presented to the sensible nature of man as an extraneous force of restrictive character, and it acts as a cohesive power, even when it is subjective in origin. To this it is necessary to add that the "must be" is conceived as a multiplicity of nonorganically linked imperatives, which often determines conflict. Thus, the conflict between $l$ aw and human inclination is linked to the internal conflict regarding the various spheres and types of duty. Consequently, religious life is not placed within the domain of ethics, which would presuppose the elimination of the "break" and of a passage to a different dimension in which the opposition between law and inclination or the conflict of opposing duties would not occur. Such a dimension is then represented as that of love; as the center of Jesus' predications, it is directly linked to God and unites God and man through the evangelic message.

As a result, the problem of "break" reappears as that of the processes within the relationships of ethic (or positive religion) and love. In the dimension of love is solved the opposition, the conflict between $i$ aw and human inclination; the conflicts derived from the multiplicity of incompatible duties is resolved, and thus the unity of life is re-established. Thus:

... love does not express any essential duty inasmuch it is not an universal element in opposition to a specific determination; and it is not a conceptual unity (eine Einheit des Begriffs), but rather the singular unity of the spirit (Einigkeit des Geistes), divine support (Göttlichkeit); to love God means to feel in the totality of 1 f fe, without limit, to the infinite... (Noh1, 1907:296).

In the determination of this relationship surfaces specifically the first open expression of the Hegelian dialectic. In fact, the dialectic process as a process of solution of the oppositions through the reunification of opposites, which has its core in the elimination of a "break" through the "solution" of such opposition in a higher unity, recognized as the basis of both, appears already defined in the essays of this period. Moreover, the two fundamental moments of the "break" (which lead to the opposition) are al ready also determined at the moment of reunification.

It is important to underline that the definition of the diajecticajporocess during the period at Frankfurt occurs in a discussion of religious and brings with it a series of implications that underline the diajectictioth. such ethico-political character. Moreover, it is applied in analysisyofspecific 
religious questions, such as that of the question of the Trinity and the mediating role of Christ (Noh1, 1907:309-10).

Through such an analysis Hegel reaches the expression of the central presuppositions of romantic culture, that of an identification between finite and infinite. Divine substance is the specific spiritual essence of life; and life is intrinsically infinite, thus the union of infinite and finite; or, in a more specific Hegelian formulation, the moment manifested by a series of finite determinations which are continuously resolved in its infinite process. Thus, from the theological problem of incarnation (Menschwerdung) of God (that represented the salvation of the world of sin and the reconciliation with such world of man with God because of divine initiative), emerges the problem of mediation, posited as the search of a dialectical mediation that can be reached through the elimination of the "break" and the conquest of unity beyond the plane of the isolated existence of opposite terms (Niel, 1945, chapter 1).

Moreover, the question also emerges in the most mature writing of the Frankfurt period (Systemfragment), where the "break" is defined as opposition between the unity of $1 i \mathrm{fe}$ and the multiplicity of its particular determinations, and the question of reunification becomes the conquest of a unity-totality that includes as $i$ ts own the necessary moments of determination (Häring, 1929-38:536; De Negri, 1943:66-71). The emergence of opposition is inherent to the continuous becoming of life in multiple individual forms, in a plurality of "beings," since on the one hand the multiplicity of the particular determinations is opposed to life in its unity which in itself remains abstract, and on the other hand one individual, isolated from others, is placed in opposition to the other.

The concept of individuality implies the opposition in the confrontation of infinite multiplicity and in conjunction with such multiplicity. A man is an individual life inasmuch he is that in relation to all the other elements, and inasmuch the infinity of individual life exists outside him; and he is only inasmuch the totality of life is divided--he is a part in relation to which the remainder constitutes the other part, and only while it is not a part and nothing is separated from him. Presupposing and establishing the indivisibility of life, we can consider the living beings as manifestations of life and as its representation-there is then the multiplicity in its temporality, and unity in its a-temporality; thus, life, while grasped from the oustide, our limited life, is shown as infinite, or infinite multiplicity, of infinite opposition, of infinite relationships; and it is as plurality an infinite plurality of organization and individuals, and as unity a sole totality, organized, internally differentiated, and unified---that is, nature (Noh1, 1907:346-7).

Thus, the spiritual essence of life expresses the coincidence of infinite and finite at the moment that the individual determination of life is solved in $i$ ts unity-totality, and becomes a necessary element. Such solution becomes possible, considered in its logical perspective, if we go beyond the limits of reflexion which isolate the individuals. And, at this point, in the development of Hegelian thought, emerges the problem of determining an organ gnoseologically capable of breaking out of the isolating procedure of reflection, and grasping the process of life in its unity of "synthesis and antithesis" (Nohl, 1907:348). In the essay Der Geist des Christentums und sein Schicksal, such 
function was given through love, religion then being considered as culmination of love; similarly in the Systemfragment, religion is indicated as the organ that makes possible "the rise from finite to infinite" (Nohl, 1907:350). It is a solution that Hegel will soon abandon in the first writings of the Jena period, replacing religion by speculative reason. In the earlier Volksreligion und Christentum he had affirmed by analogy with love, in opposition to intellect, which was the organ of reflection. It is also important to indicate that in the Systemfragment there is a preoccupation with the definition of the structure of the dialectical process, which corresponds to an attempt to specify the logical dimensions of the type of consideration that intends to view life as a dialectical process. Thus, in such regard, the dialectic is conceived on the one hand as the metaphysical structure of life (a structure that has its fundamental moments in the "break" and in the "reunification"), and on the other hand as the logical structure of the procedure through which life can be grasped. To the form of abstract unity, of multiplicity, and of unity-totality corresponds the conceptual moments (defined according to a terminology discussed in the Fichtean wissenschaftslehre), of thesis, antithesis, and synthesis. Thus, the dialectic reveals itseTf in its two faces, metaphysical and logical.

\section{The Relationship Between Immediacy and Mediation}

Developed as a means for the solution of problems of a religious nature, to which there is always an ethico-political dimension (in relation to the theological theme of incarnation, translated into the research of a mediation between God and the world), the Hegelian dialectic is already defined in its basic elements at the end of the years in Frankfurt. Although that period might be interpreted as a period of crisis in the development of Hegelian thought (Lukacs, 1948), such preoccupations continue during the Jena period in the Phenomenology of the Mind and other writings. When Hegel intervenes (at Jena) in the German philosophical debate, taking a leading position in contemporary thought in the polemics between Fichte and Schelling, he has already a doctrinal framework well delineated. In the essay Differenz des Fichte'schen und Schelling'schen Systems der Philosophie (T801), and in the writings published in the Kritisches Journal der philosophie $\left(\begin{array}{ll}1 & 02\end{array}\right)$, the dialectic is developed in its logical character to become the central nucleus of a methodology for the analys is of his problems.

In the Systemfragment, Hegel had counterpoised the "isolating" reflection that is concerned with the specification of the particular determination of life and separated it from "religion" as the procedure for "reunification." Now the antithesis is presented in a different form, as the opposition between the intellect and speculative reason; and simultaneously the problem of accomplishing the transition from one to the other appears. The intellect is the gnoseologic organ that collects reality in its opposition; it is considered the multiplicity of individual determinations as a multiplicity of independent terms and in counterposition to the absolute. Such reformulation leads now to the antithesis between finite and infinite. Thus, "reason is placed against absolute fixation of the duplication process operated in the intellect" and re-directing the multiple determinations to their fundamental unity, so as "reunifying that which was separated" (Lasson, 1928:14). Such a situation becomes possible at the same time that reason acquires the consciousness of the "relationship with the absolute" that is intrinsic to the manifestation of life (Lasson, 1928:17), and permits the liberation of such manifestations from their character of limitation. The 
transition from intellect to reason results from philosophical reflection that proceeds against the separation and opposition to reach speculative reason. Thus, the procedure of philosophical reflection is modeled after the schema of the dialectical process in which is recognized the structure of reality: the movement from the multiplicity of the individual determinations to reach a unity-totality and of which they are a necessary moment, organically inserted in the totality of the process. Consequently, philosophy must assume a systematic form to be able to relate individual determinations into an organic totality.

Philosophy, while it constitutes a totality of knowledge produced
through reflection, becomes a system, which is an ensemble of
concepts, ruled not by the intellect but by reason. One must
show clearly the opposed, which gives the way to the limit,
the basis, and the conditions of the opposed; contrariwise,
reason reunifies these elements in contradiction, grasps them,
and solves them (Lasson, 1928:25-26).

Thus philosophy appears not only as a system for reaching the unity-totality of the manifestations of reality, but it is rather such reality in its conscious form (e.g., the ordered system of collective representations). In fact, the absolute becoming philosophical consciousness is "an objective totality," "knowledge in its totality (e in Ganzes von Wissen), "an organization of knowledge" (Lasson, 1928:21). At the apex of the dialectic process, we glimpse already in the essay on the Differenz the absolute knowledge that will become the supreme figure in the Phenomenology of the Mind, absolute knowledge as the coincidence of speculative reason and reality, and in which are solved and ordered all the determinations, and in which a specific differentiation of the two loses meaning. The substitutions of religion by speculative reason (as a means of apprehending the reunification of the opposed) is precise in a way that will remain unchanged in Hegel's later works and will remain an indispensible function of the dialectic.

If philosophy must be organized into a conceptual totality and move in the multiplicity of the individual determinations of reality to solve them in such totality, it is clear that it cannot assume the form of a set of interrelated propositions that can be deduced from a fundamental proposition, following Fichte's account in the Wissenschaftslehre. In this regard, Hegel's dialectic in the Differenz is defined polemically in relation to the Fichtean dialectic. Not only because Hegel proceeds to define the structure of the dialectical process based on very different concerns when compared to the gnoseological preoccupations of Fichte, but also because the system is re-directed to subjects quite different from the original formulations. Such aspects appear even in the Differenz where Hegel equates the equivalence of the principle of identity and that of opposition; not identify in itself but in relation to the opposition can constitute the basis of philisophy (e.g., the relational principle). The direct implication regarding Fichte is that the triadic principle cannot be considered as the expression of a deductive procedure (Lasson, 1928:38). The criticism regarding subjectivity is similarly raised to Kant in the essay Glauben und Wissen oder die Reflexionsphilosophie der Subjektivitāt (1802).

Thus, "real infinity" cannot be considered as a series of moments without conclusion; it is an inherent dimension to the individual determinations of reality, in their solution into an organic totality that comprehends them. As a result, finite and infinite cannot be viewed as extraneous terms but rather as coincidental. 
Such is above all the true nature of the finite, that it is infinite, and that it is solved in its being (finitude). The determinate element has not, as such, any other mode of being besides such absolute restlessness of not being that which it is: that it is not nothing, inasmuch it is another and that the other is the contrary of it, and nevertheless, it is that determinate element (Lasson, 1923:31).

Thus, infinity is the direct substance of the finite, the contradictory structure of reality, in virtue of which the multiplicity of its individual determinations are solved in a dialectic process: it is the "negation of the negation" that appears in the last instance as an "affirmation" (Lasson, 1923:31). In fact, any manifestation of reality, while limited, has a "negative" character (it implies or is a negation of itself in regard to the other manifestations, or in a relationship with the unity). Consequently, the negation of such manifestation, which is the elimination of isolation and limitation, is in its turn an affimation; with it the finite determination is recognized as an element part of the unity-totality. Infinity is thus the movement in the "solution of antitheses" (Lasson, 1923:33), inherent in the connections of the finite determinations of reality.

Differentiating his conception of dialectics from that of Fichte, Hegel often recalls the position of Schelling; thus, he affirms (Differenz) the fundamental affinity of his thought with that author. Moreover, the years at Jena are some of the closest collaboration between these authors on the basis of a philosophy of identity in which subject and object come to coincide, and in which the absolute is understood not any longer as pure subjectivity but rather as "the equality of identity and non-identity" (Lasson, 1928:77). From Schelling, Hegel in fact develops interest for the philosophical consideration of nature and the means to its development (Hoffmeister, 1932). Nature is a realm in which spirit subsists in a latent form, without being yet conscious of itself; and its phenomenon isprogressively resolved inasmuch as it approximates the acquisition of spiritual knowledge. To determine the rhythm of such process, Hegel refers to a previous schema of dialectic (from Frankfurt, under the infiuence of Schelling): nature is a series of "potentialities" that go beyond reason by virtue of an internal "polarity," giving place to a continuous "increment." Interpreting nature as the counterpoint of mind, as "another world regarding the world of the mind," the problem of the "deduction" of nature appears for the first time (Lasson, 1923:184-6). Such formulation will be retaken later in the Encyclopädia where Hegel orients the analysis to the determination of the conceptual structure of natural phenomena. Thus, the essence of the natural process is viewed as a series of conceptual elements that reproduce in a covered fashion the relationships of logical determinations.

Nevertheless, it is particularly in the conception of absolute (and the procedures of philosophy) that appears the difference between Hegel and Schelling. Earlier, in the polemic with Fichte (Differenz), when Hegel refers to the absolute, he means not the undifferentiated unity that annuls the individual determinations, that cancels 1 imitations and oppositions; but rather to the result of the process involving the spirit in the multiplicity of determinations resulting in a unity-totality. In such unity the determinations are maintained, not in their isolation and imitations, but rather as necessary moments of an organic totality. To this corresponds the definition of speculative reason as the supreme organ of knowing and the limitations of the functions of art: 
Its element [art] is intuition; but that is the immediacy without mediation. Thus, to the mind such element remains inadequate... It is not, really, the form of thought (Lasson, 1923:265).

Philosophy is placed above art, and includes the "form of mediation, the concept" (Lasson, 1923:267). Accordingly, it makes possible to penetrate the connections of the individual determinations of reality and to link them to a unity-totality. In other words, philosophy (while speculative reason) is the specific organ of mediation, expressing the mediation intrinsic to the structure of the mind. The mind is thus the being "that is mediated through itself, " and which exists only "solving that which is immediately" proceeding beyond immediacy (Lasson, 1923:272). The reference to itself is intrinsic to its structure, to $i$ ts own existence. In fact, every determination of the mind is an "immediate" element that requires a mediation; and such mediation is nothing but the dialectic procedure of that spiritual reality.

\section{The General Structure of the Context of Knowledge and Knowing}

In the preceeding analysis, two elements were lifted out of Hegel's early writings: those of the "break" and of "immediacy and mediation." Even in such a limited presentation there are hints that the problem discussed by Hegel is more complex. To present even a general description we would have to limit it here to the sketch of its main outlines. The general context could be described as possible lines of movement in the subject-object relation wi thin space and time. We will discuss this in what follows. Nevertheless, to give a glimpse of the added complexity of the general context, it might be enough to compare it with another classic proposition, that of Democritus (Chisholm, 1966:91-102). Thus, "the ways in which the things that we perceive appear to us when we perceive them depends in part upon our own psychological and physiological condition...Democritus took it to imply not only that we think we perceive, but also that the external things are not at all what we tend to believe they are" (Chisholm, 1966:91). As a result, those appearances "change with the condition of our body and the influences coming toward it or resisting it" (Nahm, 1934:209). The basis for the criticism of this and similar positions is founded upon a differentiation between dispositional and sensible propositions regarding a "thing" (following Aristotle). But, when we consider the context in which the question appears in Hegel (e.g., positivity of Christianism), these arguments do not apply; particularly in the radically different character of the relationships between subject-object (e.g., man-normative religion; ethics-ritualism).

A general sketch of the situation in Hegel would include the following: a) movement of the subject toward object, b) cognitive movement of subject, c) movement of subject-object within time (space)-syncronic; d) movement of subject-object through time-diachronic.

A fundamental dimension that sets the context of knowledge (knowing) is that of meanings (for example, regarding the miracles: "It is true that opponents of Christianity have advanced the considerations against the reality and philosophers against the possibility, of miracles; but this does not diminish their effect, because what is everywhere admitted, and what is enough for the argument here, is that these deeds of Jesus were miracles in the eyes of his pupils and friends" (Noh T, 1907:78). 
The predications of Jesus were fundamentally ethical, and as such "could" be perceived as truthful. Nevertheless, in their context of givenness, the process of "knowing" them could not be summed into the dimension (a) above (that is, a movement of subject--man, Jews, Jesus " followers and friends---simply toward the object---the ethical enunciations). Social and cultural accretions to the context of meaning lead to perceptual apprehension (e.g., they were viewed from the perspective and the socio-cultural background of judaism; they were immediately linked to the person of Jesus, etc.), so as that already in the dimension (b) above, the cognitive movement of the subject to object, these accretions appear. As a result, the complexity of dialectical analysis at this level already entails the concomitant analysis of three nexus of relationships: subject-object, their synchronic relations, and their diachronic relations, in a process of surpassing each of the particular objective manifestations and transcending them into a new dynamic "totality."

\section{References}

Chisholm, Roderick M.

1966 Theory of Knowledge. New York: Prentice-Hal1.

De Negri, Emilio

1943 Interpretazione di Hegel. Florence: Sansoni.

Dil they, Wilhelm

1907 Hege $1 s$ Theologische Jugendschriften. Tubingen: Mohr.

1921 Gesammel te Schriften: Die Jugendgeschichte Hegels und andere Abhandlungen zur Geschichte des deustschen Idealismus. Leipzig: Teubner.

Haring, Theodor

1929-38 Hegel, sein Wollen und sein Werk. 2 vols. Leipzig and Berlin: Teubner.

Hegel, G. W. F.

1793-4 Volksreligion und Christentum.

1795 Das Leben Jesu.

1795-6 Die Positivität der Christlichen Religion.

1798-9 Der Geist des Christentum und sein Schicksal.

1800 Sys temfragment.

1801 Differenz des Fichte'schen und Schelling'schen Systems der Philosophie.

1802 Glauben und Wissen oder die Reflexionphilosophie der Subjektivität.

Hoffmeister, Johannes

1931 Hölderlin und Hegel. Tübingen: Mohr.

1932 Goethe und der deutsche Idealismus: Eine Einführung zu Hegels Realphilosophie. Leipzig: Meiner Verlag. 
54 Kansas Journal of Sociology

Lasson, Georg

1923 Jeneser Logik, Metaphysik und Naturphilosophie. Leipzig: Meiner Verlag.

1928 Erste Druckschriften. Leipzig: Meiner Verlag.

Lukacs, Georg

1948 Der junge Hegel" Über die Beziehungen von Dialektik und Ökonomie. Zurich and Wien: Europa Verlag.

Nahm, Milton

1934 Selections from Early Greek Philosophy. New York: Appleton-CenturyCrofts.

Niel, Henry

1945 De la mediation dans la philosophie de Hegel. Paris: Aubier.

Nohi, Herman

1907 Hegels Theologische Jugendschriften. Tubingen: Mohr.

Scheler, Max

1926 Die Wissenformen die Gesellschaft. Leipzig: Der Neue Geist Verlag.

1928 Die Stelling der Menschen in Kosmos. Leipzig: Der Neue Geist Verlag. 